\title{
高度経済成長期から現在へ 〈日本型社会システム〉をどのように評価するか一
}

\section{1 「高度経済成長期」へのまなざし}

本特集のタイトルには、三つの重要なキ一ワードが含まれている。「高度経済成長期」、「日本型 システム」、学ぶ」の三つである。これらはいずれもよく知られ、よく使われる言葉であるが、 文脈によってきわめて多義的でもある。そこでまず、これらの用語の含意について整理するとこ ろからはじめよう。

戦後日本経済は、一般に三つの時期に分けられる。1955年から1973年までの高度成長期、 1974年から1990年までの安定成長期、1991年から現在に至る低成長期である ${ }^{\prime}$ (図 1)。近年、 日本経済には改善の兆しがあり、大学生の就職率も2017年度は過去最高を記録したと報じられて いる。しかしその一方で、過重労働による目殺やうつ病の多発、ワーキングプアや子どもの貧困、 貧富の格差の拡大などが社会問題化している。

1991 年以降の低成長期は「失われた20年」とも呼ばれ、社会の閉塞感を指摘する声もある。そ のような状況の中で、メディアでは映画『ALWAYS 三丁目の夕日』 ${ }^{2}$ に代表されるような高度成長 期へのノスタルジー、あるいはバブル時代への憧れなどが大きく取り上げられている。しかし、 高度成長期の実態を考えれば、そのようなイメージにはいささかの違和感を感じざるを得ない。

たとえば、『ALWAYS 三丁目の夕日』は、東京タワ一の建設を背景に、1958年、近所の自動車 修理工場に青森から集団就職してきた少女を中心とした人びとの心の交流が語られる。映画とし て観客を感動させる作品であり、多くの映画賞を受賞した。だが、当時の現実は必ずしも誰にとつ ても優しいものではなかった。1965年に青森から集団就職してきた永山則夫は、自分の居場所を 見つけられず、1968年、東京夕ワ一の真下にある東京プリンスホテルでガードマンを射殺した。 永山事件については、見田宗介（1973）による的確な分析がある。

戦後広く行われた集団就職とは、地方から新規中卒者が大量に都市部に就職する雇用形態をい う。就職先は小規模な商店や工場が多く、「金の卵」とは呼ばれても、労働条件や生活環境は厳しく、 転職率、離職率はきわめて高かつた。

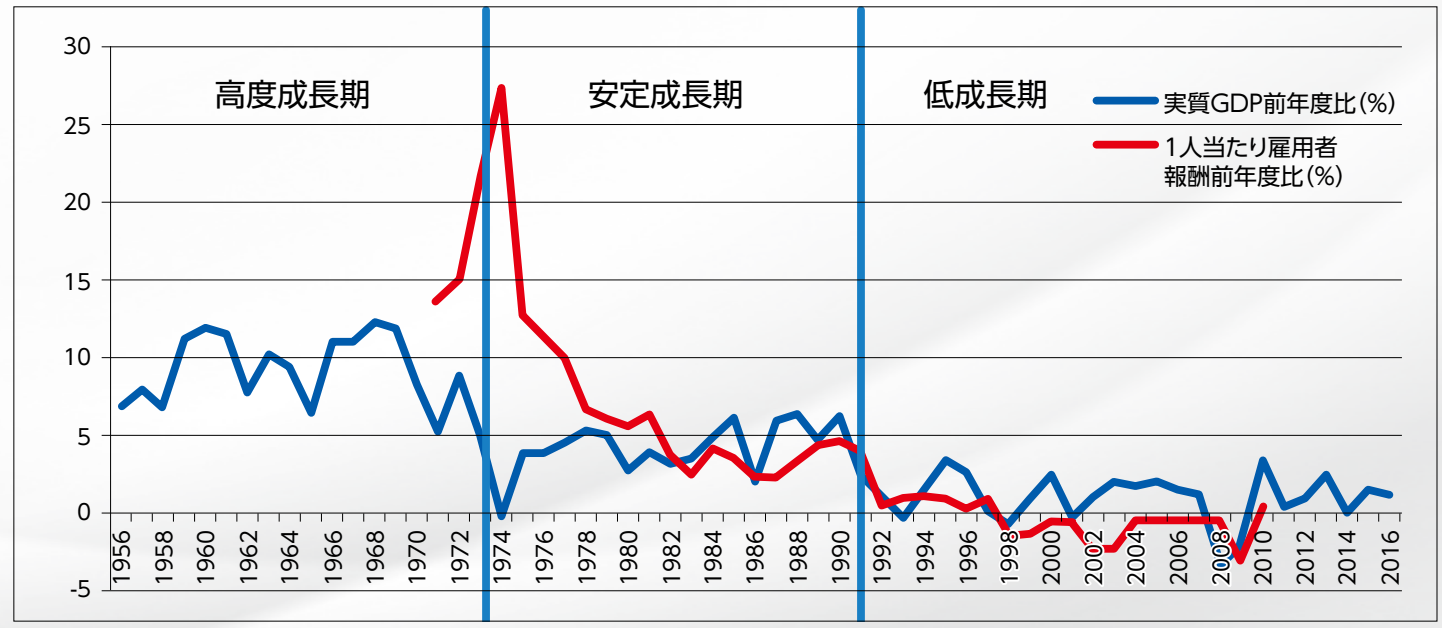

図1 高度成長期から現在まで 3 


\section{2 「日本型システム」とは？}

\section{1 「日本型システム」と経済成長}

それでも、戦後の焼け跡から短期間に成し遂げられた経済復興は、世界から驚きをもって「東 洋の驚異」と呼ばれた。なぜそのような経済成長が可能だったのか。国内外から日本の経済や社 会の特性について多くの分析がなされた。そのときにしばしば使われたのが、「日本型システム」 あるいは「日本型モデル」という用語である。

もつとも、「日本型システム」という言葉は、必ずしも高度経済成長期の社会に限って使われる ものではない。たとえば、経済学者の吉田和男は次のように述べている。

今日、日本型システムに対する関心が世界的に強くなっている。これは日本経済の発展の 驚異だけでなく、これにともない、経済摩擦を引き起こすなど、世界でのプレゼンスの大き さがそうさせている。いわゆる近代化に成功した日本は、世界を支配したヨ一ロッパに対し て本格的に対抗した唯一の存在であった。その挑戦のピークとなった大東亜戦争に敗北する ことで、その予先を経済面に集中することとなった。そこで、経済大国となった日本の経済 的プレゼンスが再び世界からも注目を集めることになる。（吉田1996:355）

この引用文から少なくとも、「日本型システム」は、明治維新後の急速な近代化（経済成長）亡、 第二次世界大戦後の急速な復興（経済成長）の二度にわたって、「経済成長」をキ一として注目さ れたことがわかる。

ただし、「日本型システム」は国内においても必ずしもポジティブにばかり評価されてきたわけ ではない。比較社会学を專門とする濱口惠俊（1993）は次のように指摘する。

日本の文化·文明·社会·国民性などを分析する場合、これまでともすれば、「集団主義」「恥」 「夕テ社会」「集団我」「甘え」といったキーワードで包括的にとらえられることが多かった。 そこでの分析では、日本人はともすれば行動上の主体性を欠き、したがってまた、それぞれ が個人としてのユニークな意見をもたない、きわめて同質的な民族（国民）であって、その 所属する組織に完全に埋没してしまっている、と見なされた。(p.3)

\section{2 「日本型システム」論と日本特殊論}

「日本型システム」に対して批判的であるにせよ肯定的であるにせよ、その基底には、しばしば「日 本特殊論」がある。濱口（1998）は、次のように述べている。

日本研究において、「日本特殊性論」「日本異質論」と呼ばれる論議が、よく引き合いに出され、 何となく定着化したかのようにもみえる。しかしそこでは、日本側の研究者が、自らの文化 的特性を十分な根拠もなく持ち上げたり、その反対に、海外のリビジョニストと称される評 論家が、世界で普通に見られるものが日本ではまるきり欠如しており、まるで異星人の文化 のようだと貶めたりするのである。いずれの場合も、科学的に日本をとらえているとは言い 難い。

日本的特性亡されたものが、よく調べれば他の社会にも遍在するでくありふれた事象に過 ぎなかったり、あるいは、日本でしか通用しないと考えられていた事柄が、意外にも海外で 受け入れられたりするケースも少なくない。たとえば、QCサークル活動のように。さらに 言えば、日本がかりに文化的にユニークであるとしても、同様の意味で、他の社会もまた特 異なのであって、それぞれの特質は、本来、文化相対主義的に理解されるべきものであろう。 どの社会もそれぞれに違っているのであって、ただ日本だけが特殊・異質である、と極め付 けるわけにはいかない。(濱口1998：ii）

このような観点から、「日本の社会と文化を一つのまとまりのあるシステムとしてとらえ、それ 
を国際社会の中に正しく位置付けて把握しよう」（同上）と、濱口は主張している。

\section{3 「日本型システム」の通時性と共時性}

社会学の領域では、その非合理性、前近代性に対する批判 がーつのテーマであつたといってもよい。とくに経済成長を 目標として社会のサブシステムを編制していくことに対して は、クリティカルな眼差しが向けられざるを得ない。先に挙 げた「集団就職」も、高度成長期における日本特有の雇用シ ステムであった。

すなわち、「日本型システム」は、「高度経済成長」という 目的に対しては合理的であったかもしれないが、社会全体や 個々の生活者にとって喜ばしいものであったかは別の問題だ からである。また「日本型システム」が「高度経済成長」に

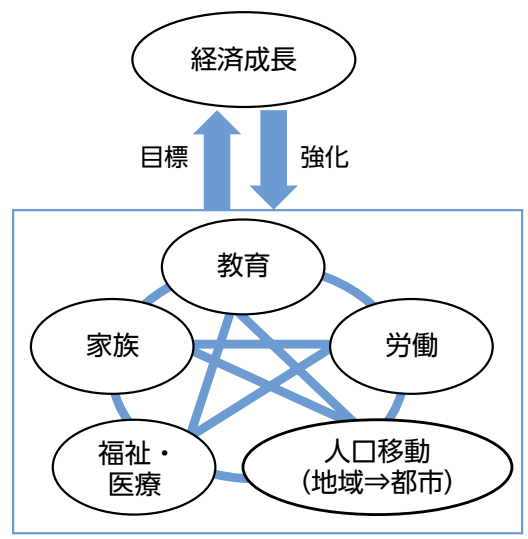

図2 経済成長と「日本型システム」 正の機能をもたらすのであれば、「高度経済成長」は再帰的に「日本型システム」を強化したかも しれない。ただし、ごこかの時点でそれが逆機能に転じた可能性もある(図2)。

一方、「高度成長期」の「日本型システム」は、「文明開化」期の「日本型システム」と同じな のだろうか。そもそも「日本型システム」は、たとえば丸山眞男が「日本文化の古層」と呼んだ ものと一致するのだろうか。違うものなのだろうか。

あるいは「高度経済成長期」の「日本型システム」が、現在の「日本型システム」にどのよう につながっているのだろうか。

\section{3 われわれは過去から何を学び得るのか、学び得ないのか。}

以上の論点を踏まえた上で、本特集は、「日本型システム」を、海外（特に欧米）の社会システ ムとの比較というよりは、むしろ、「高度成長期」における日本社会の「(サブ）システム」につ いて、全体システムとの関係を、現在という時点から、再検討、再評価する試みである。そこから、 「失われた $\times \times$ 年」といわれるような曖昧な閉塞感を脱却して、日本社会の未来を展望する視野を 開くことが本特集の目的とするところである。

日本学術会議第一部会員・社会学委員会委員長 学習院大学法学部教授 遠藤 薰

\section{参考文献}

遠藤薰, 2008, 「東京タワーをめぐる三つのよるべない物語——情 報化社会における雇用流動化と〈コミュニティ〉」遠藤薫·編著『ネッ トメディアと〈コミュニティ〉形成』東京電機大学出版局, 97118.

遠藤薰 , 2016,「日本における社会システム論の意義と未来—— 本近代と自己組織性」遠藤薰・佐藤嘉倫 · 今田高俊編『社会理論の 再興——社会システム論と再帰的自己組織性を超えて』ミネルヴァ 書房, 331-352.

濱口惠俊, 1993, 『日本型モデルとは何か一一国際化時代における メリットとデメリット』新曜社.

濱口惠俊, 1998,『世界のなかの日本型システム』新曜社.

見田宗介, 1973, 「まなざしの地獄—都市社会学への試論」『展望』 (173) , 98-119, 1973-05 筑摩書房.

吉田和男, 1996, 「曰本型システムの特殊性亡普遍性」『日本研究 · 京都会議』non01-01, 355-372.
注

1 期間については、論者によって若干のずれがある。

2 西岸良平の漫画『三丁目の夕日』を原作とした劇場映画。 2005 年公開。山崎貴監督。

3 データ出所: 2016 (平成 28) 年度 国民経済計算年次推計 （2011 年基準·2008SNA），1998（平成 10）年度 国民経 済計算確報（1990 年基準・1968SNA）（1955 年～1998 年、付表一部 $1970 \sim 1998$ ) (平成 12 年版国民経済計算 年報 ）http://www.esri.cao.go.jp/.jp/sna/data/data_list/ kakuhou/files/files_kakuhou.html 